\title{
Evaluation of Certain Agrochemical and Biological Agents Against Meloidogyne incognita on Tomatoes
}

\author{
Hala S. Ibrahim ${ }^{1}$ Abdel-Fattah S. A. Saad ${ }^{2}$ Magdy A. Massoud ${ }^{2}$ Mohamed S. H. Khalil $^{3}$
}

\begin{abstract}
An experiment was conducted in a greenhouse to evaluate the biological performance of some agrochemical and biological agents against root-knot nematode on tomatoes planted in clay soil. The antagonistic bacterium Pseudomonas flouroscence was proved to be the most effective tool suppressing the infection of root-knot nematodes on tomatoes during the period of inspections. The mean of population reduction of $P$. flouroscence was (79.4\%), followed by the mixture of antagonistic fungus and bacterium Trichoderma harazianum plus Pseudomonas flouroscence $(73.0 \%)$, then fosthiazate $(60.3 \%)$, while the least effective one was abamectin $(22.5 \%)$.

On the other hand, abamectin applied as soil drench gave the highest reduction percentage $(81.6 \%$ of root galls / $5 \mathrm{~g}$ roots) followed by oxamyl $(62.4 \%)$, then fosthiazate $(61.5 \%)$. Carbofuran recorded the least reduction percentage of $33.1 \%$ of root galls $/ 5 \mathrm{~g}$ roots.

Meanwhile, abamectin gave the highest reduction percentage on egg masses / $5 \mathrm{~g}$ roots $(79.1 \%)$, followed by oxamyl and $\boldsymbol{P}$. flouroscence giving 61.4 and 39.9 reduction percentages. The least effective treatment was Trichoderma harazianum which increased the egg masses by $18.8 \%$.

Some treatments showed an indirect effect on the root and shoot system length and weight. The antagonistic fungus Trichoderma harazianum was the superior treatment which increase the root system length by $39.1 \%$, whilst abamectin didn't show any increase.

Trichoderma harazianum as well as fosthiazate proved to be the most effective treatment on the root system fresh weight as they gave 86.8 and $85.5 \%$ increase, respectively. Abamectin was the least effective treatment giving $5.3 \%$ increase.

On the other hand, $T$. harazianum was effective and gave the highest increase percentage of shoot system length followed by oxamyl (54.9 and $46.8 \%$, respectively). Meanwhile, the same trend was obtained in case of shoot system weight giving increases of 87.8 and $81.9 \%$, respectively. Abamectin treatment was the least efficient on its effecton both root system length and weight increase.
\end{abstract}

\section{INTRODUCTION}

Tomato fruits are considered to be one of the important nutritive sources for carbohydrates, minerals and vitamins. Tomato plants (Lycopersicon esculentum Mill) represent an important vegetable crop in Egypt, showed that [every $100 \mathrm{~g}$ contains: $4.7 \mathrm{gcarbohydrates,}$ $1.1 \mathrm{~g}$ protein, $0.2 \mathrm{~g}$ fats, $0.5 \mathrm{~g}$ fiber, $13 \mathrm{mg}$ calcium, $27 \mathrm{mg}$ phosphor, $244 \mathrm{mg}$ potassium, $3 \mathrm{mg}$ sodium, $0.5 \mathrm{mg}$ iron, $23 \mathrm{mg}$ ascorbic acid, $0.06 \mathrm{mg}$ thiamin, $0.04 \mathrm{mg}$ riboflavin, $0.7 \mathrm{mg}$ niacin and 900 iu vitamin A] (Howeedy et al., 2003).

The production of tomato plants is affected by several factors mainly, rain fall, temperature, soil fertility, time of planting, plant density, infestations of destructive pests and diseases infection that cause great loss and damage. The root-knot nematodes, Meloidogyne spp., have been recognized as one of the serious pests causing remarkable losses of vegetables production especially tomato crop (Ibrahim, 1985).

Among the root-knot nematodes, Meloidogyne javanica, M. incognita, M. arenaria, and M. hapla, are of major agronomic importance, being responsible for at least $90 \%$ of all damage caused by these nematodes (Castagnone-Sereno, 2002). These nematodes can be a particular menace in third world countries where most peasant farmers are unaware of these "hidden enemies" and do not take steps to manage them.

Fumigant and non-fumigant nematicides have been used against plant-parasitic nematodes with good results since 1950s. They have been used extensively for controlling root-knot nematode that threat the production of many fruits, vegetables and nursery crops (Noling and Becker, 1994).

There is a general agreement that the toxic action of organophosphate and carbamate pesticides upon nematodes and insects is caused by their ability to inhibit acetylcholinesterase (AChE) in various parts of the nervous system, thereby, disrupt nervous transmission at that location (Corbett et al., 1984). Using biopesticides being a new line developed and improved to be an important tool in the IPM programs.

The aim of the present study is to investigate the effectiveness of some agrochemical and biological agents against the root-knot nematodes, Meloidogyne

\footnotetext{
${ }^{1}$ Central Agricultural Pesticides Laboratory,

Agric.Res. Center, Dokki-Giza.

${ }^{2}$ Department of Plant protection, Faculty of Agriculture Saba pasha,

Alexandria University.

${ }^{3}$ Central Agricultural Pesticides Laboratory, Agric.Res. Center,

El-sabaheya, Integrated Protection Laboratory, Alexandria.

Received January18, 2010, Accepted Febuary10, 2010
} 
incognita, and to through a light on the antagonistic microorganism as safety methods to reduce effectively the population density of plant-parasitic nematodes in the soil.

\section{MATERIALS AND METHODS}

\section{Agrochemical and biological agents:-}

- Nematicides Used:

A: Organophosphorus

1) Nemathorin ${ }^{\circledR} 10 \% \mathrm{G}$ (fosthiazate), [RS-S-sec-butyl $O$ ethyl2-oxo-1,3-thiazolidin-ylphosphonothioate; $(R S)$ 3-[sec-butylthio(ethoxy)phosphinoyl]-1,3thiazolidin-2-one].

2) Rugby ${ }^{\circledR} 10 \% \mathrm{G}$ (cadusafos), [S, $S$-di-sec-butyl $O$ ethyl phosphorodithioate].

\section{B: Carbamates}

1)Cartan ${ }^{\circledR} 10 \% \quad$ G $\quad$ (carbofuran),[2,3-dihydro-2,2dimethylbenzofuran-7-yl methylcarbamate].

2)Vydate ${ }^{\circledR} 10 \% \quad$ G $\quad$ (oxamyl), [N, $N$-dimethyl-2methylcarbamoyloxyimino-2-(methylthio)

acetamide].

\section{- Biopesticide agents:}

Vertemic $(1.8 \% \mathrm{EC}$ (Abamectin),(10E,14E,16E,22Z)$(1 R, 4 S, 5 ' S, 6 S, 6 ' R, 8 R, 12 S, 13 S, 20 R, 21 R, 24 S)-6$ '-[(S)-secbutyl]-21,24-dihydroxy-5',11,13,22-tetramethyl-2-oxo$3,7,19$-trioxatetracyclo $\left[15 \cdot 6 \cdot 1 \cdot 1^{4,8} \cdot 0^{20,24}\right]$ pentacosa10,14,16,22-tetraene-6-spiro-2'-(5',6'-dihydro-2' $H$ pyran)-12-yl 2,6-dideoxy-4- $O$-,6-dideoxy-3-O-methyl$\square$-L-arabino-hexopyranosyl)-3-O-methyl- $\square$-L-arabinohexopyranoside(i)mixture with $(10 E, 14 E, 16 E, 22 Z)-$ $(1 R, 4 S, 5 ' S, 6 S, 6 ' R, 8 R, 12 S, 13 S, 20 R, 21 R, 24 S)-21,24-$ dihydroxy-6'-isopropyl-5',11,13,22-tetramethyl-2-oxo$3,7,19$-trioxatetracyclo[ $\left[15 \cdot 6 \cdot 1 \cdot 1^{4,8} \cdot 0^{20,24}\right]$ pentacosa10,14,16,22-tetraene-6-spiro-2'-(5',6'-dihydro-2' $H$ pyran)-12-yl 2,6- dideoxy-4-O-(2,6- dideoxy-3-5 methyl- $\square$-L-arabino- hexopyranosyl)-3-O-methyl- $\square$-Larabino-hexopyranoside (ii) (4:1) .

\section{- Antagonistic Fungus (Trichoderma harazianum).}

The fungus Trichoderma harazianum was obtained from the biofertilizer center, Ain Shams University. The suspension was counted under the microscope. It is found that each $\mathrm{ml}$ contains $1 \times 10^{5}$ spore. The treated plants received $50 \mathrm{ml}$ of the suspension $\left(5 \times 10^{6}\right.$ spore / plant).

\section{-Antagonistic}

Bacterium

(Pseudomonas flouroscence).

The bacterium Pseudomonas flouroscence was also obtained from the biofertilizer center, Ain Shams University. The suspension was counted through the spectrophotometer at the wave length of $550 \mathrm{~nm}$. The optical densities were measured and compared with the standard curve and found that each ml contains $3.8 \times 10^{4}$ CFU. The treated plants received $50 \mathrm{ml}$ of the suspension (1.9 $\times 10^{6} \mathrm{CFU} /$ plant). mixture of the antagonistic fungus and the antagonistic bacterium ( half dose of both $\left(2.5 \times 10^{6}\right.$ spore $)+\left(95 \times 10^{4} \mathrm{CFU}\right) /$ plant $)$ was also evaluated.

\section{The Greenhouse Experiment.}

Greenhouse experiment was carried out on tomato plants cv. Super strain B as a host plant for plant parasitic nematodes (Meloidogyne incognita), in the Faculty of Agriculture Saba-Basha greenhouse. The greenhouse contained clay soil $(89.5 \%$ clay, $0.5 \%$ sand and $10 \%$ silt). There were 9 different treatments and each treatment consisted of ten replicates (a plant / replicate).

The Soil samples were took according to Barker (1985) for three successive months after treatment to determine the efficacy of the tested compounds on the nematode populations in the soil. The shoot length, shoot weight, root length, root weight, galls number $/ 5 \mathrm{~g}$ root, egg masses / $5 \mathrm{~g}$ root system and number of juveniles / $250 \mathrm{~g}$ soil were determined. The roots were stained for 15 minutes in an aqueous solution of phloxine B stain $(0.15 \mathrm{~g} / \mathrm{l}$ water $)$ then they have been washed with running tap water to remove the residual of the stain. To detect the presence of nematode egg masses, the mothod of Holbrook et al.(1983) was followed.

The reduction percentage of infection was calculated after 1, 2 and 3 months post-treatment according to the formula of Henderson and Tilton's (1955) as follows:

Reduction $\%=\left\{1-\left(\frac{\mathrm{a}}{\mathrm{b}} \times \frac{\mathrm{c}}{\mathrm{d}} \quad\right)\right\} \quad \mathrm{x} \quad 100$

Where:

$\mathrm{a}=$ Population in treatment after treatment

$\mathrm{b}=$ Population in treatment before treatment

$\mathrm{c}=$ Population in check untreated (control) before treatment

$\mathrm{d}=$ Population in check untreated after treatment

The fertilizationof plants was carried out daily through the drip irrigation lines (fertigation). The irrigation was performed through the drip irrigation lines two times / day.

Data of the present study were subjected to the analysis of variance test (ANOVA) as complete randomized design for greenhouse experiment. The least significant difference (LSD) at the 5\% level of probability was determined using a computer program Costat and Duncan's Multiple Range (Duncan, 1955). 


\section{RESULTS AND DISCUSSIONS}

1) The effect of the tested agrochemical and biological agents against the nematodes populations:

The data in Table (1) show the calculated reduction percentages of the tested agrochemical and biological agents on the second stage Juvenile number $\left(\mathrm{J}_{2}\right)$ at $250 \mathrm{~g}$ clay soil in the greenhouse experiment. The efficacy of the used agrochemical and biological agents [nematicides, biopesticide and antagonistic (fungus/bacterium)] were monthly recorded for three months post-treatment, and the efficacy of the agrochemical and biological agents were varied.

It is obvious that the efficacy of the tested agents and chemical was increased in the second month except cadusafos. On the third month, it was noticed that the efficacy of all treatments decreased except the antagonistic bacterium Pseudomonas flouroscence and the mixture of antagonistic bacterium and fungus Pseudomonas flouroscence plus Trichoderma harazianum. Generally, the most effective treatment was Pseudomonas flouroscence against nematode population which recorded a reduction of nematode population calculated by $79.4 \%$. Afterwards, the treatments of Trichoderma harazianum plus Pseudomonas flouroscence, fosthiazate, oxamyl, carbofuran, Trichoderma harazianum, cadusafos and abamectin showed the following reduction percentages of the nematodes population 73.0, 60.3, 60.0, 43.8, 43.2, 41.8 and $22.5 \%$, respectively.

These findings are in agreement with those reported by Sharma (1999) and Krishnaveni and Subramanian (2004) indicated that Trichoderma harzianum, Trichoderma viride and $P$. fluorescens were effective in controlling the plant parasitic nematodes. On the other hand Stephan (1995) and Badawi and Abu-Gharbieh (2000) showed that the treatments of following nematicides: Cadusafos liquid, carbofuran and oxamil were effective in controlling $M$. javanica. Monfort et al.(2006) and Faske and Starr (2007) indicated that abamectin has a nematicidal effect against $M$. incognita and Rotylenchulus reniformis on cotton plants.

The possible mode of action of the antagonistic bacterium Pseudomonas fluorescens strain that it produces hydrogen cyanide $(\mathrm{HCN})$, as a secondary metabolite (Imran et al., 2006) and that gas has its effect on nematode. The suppression of nematode multiplication by Pseudomonas fluorescens could be due to its capability of altering root exudates which alter nematode behavior and suppress nematode population in root system (Oostendrop and Sikora, 1989).

Furthermore, the action of the antagonistic bacterium against plant parasitic nematode could be explained due to the antibiotic production and competition with pathogens for essential nutrients such as iron, and more indirectly through plant growth promotion (Gamlie and Katan, 1993 and Siddiqui and Mahmood, 1998).

2) The biological performance of agrochemical and biological agents on root galls and egg masses

Data represented in Table (2) indicated the influence of the agrochemicals and biological agents on the galls and egg masses / $5 \mathrm{~g}$ root in the clay soil. Abamectin was the most effective treatment which recorded $81.6 \%$ reduction of root galls, followed by oxamyl, fosthiazate, cadusafos, Trichoderma harazianum, Pseudomonas flouroscence, Trichoderma harazianum plus Pseudomonas flouroscence and carbofuran which gave $62.4,61.5,56.2,51.9,46.8,34.5$ and $33.1 \%$ reduction, respectively.

\section{Table 1. The effectiveness of the tested agrochemical and biological agents expressed as mean reduction $\%$ of nematode populations}

\begin{tabular}{|c|c|c|c|}
\hline \multirow[b]{2}{*}{ Treatments } & \multicolumn{3}{|c|}{$\begin{array}{c}\text { The mean reduction }(\%) \text { of nematodes populations at different } \\
\text { intervals post treatment (months) }\end{array}$} \\
\hline & $\begin{array}{c}\text { One month after } \\
\text { treatment }\end{array}$ & $\begin{array}{l}\text { Two months after } \\
\text { treatment }\end{array}$ & $\begin{array}{c}\text { Three months after } \\
\text { treatment }\end{array}$ \\
\hline Fosthiazate & 24.4 & 80.3 & 60.3 \\
\hline Carbofuran & 46.1 & 71.0 & 43.8 \\
\hline Cadusafos & 69.4 & 42.4 & 41.8 \\
\hline Oxamyl & 43.7 & 73.6 & 60.0 \\
\hline Abamectin D* & 31.5 & 58.9 & 22.5 \\
\hline Trichoderma harazianum & 52.2 & 60.2 & 43.2 \\
\hline Pseudomonas flouroscence & 30.7 & 72.0 & 79.4 \\
\hline Trichoderma h. + Pseudomonas $f . * *$ & 38.9 & 46.5 & 73.0 \\
\hline
\end{tabular}

*(D): Soil drench application at the rate of $11.11 \mathrm{ml} / \mathrm{l}$.

** The mixture was composed by the half dose of each $\left(2.5^{*} 10^{6}\right.$ spores $\left.+95^{*} 10^{4} \mathrm{CFU}\right) /$ plant. 
Table 2. The effectiveness of the tested agrochemical and biological agents expressed as reduction \% of galls and egg masses

\begin{tabular}{lcccc}
\hline \multirow{2}{*}{ Treatments } & \multicolumn{2}{c}{ Egg masses / 5g roots } & \multicolumn{2}{c}{ Galls / 5g roots } \\
\cline { 2 - 5 } & $\begin{array}{c}\text { Average } \\
\text { (NO.) }\end{array}$ & $\begin{array}{c}\text { Reduction } \\
(\%)\end{array}$ & $\begin{array}{c}\text { Average } \\
(\mathbf{N O} .)\end{array}$ & $\begin{array}{c}\text { Reduction } \\
(\boldsymbol{\%})\end{array}$ \\
\hline Fosthiazate & $328.3 \mathrm{bc}$ & 61.5 & $450.0 \mathrm{abc}$ & 22.8 \\
Carbofuran & $570.0 \mathrm{~b}$ & 33.1 & $396.7 \mathrm{bc}$ & 31.9 \\
Cadusafos & $373.3 \mathrm{bc}$ & 56.2 & $353.3 \mathrm{bcd}$ & 39.4 \\
Oxamyl & $320.0 \mathrm{bc}$ & 62.4 & $225.0 \mathrm{~cd}$ & 61.4 \\
Abamectin D* & $156.7 \mathrm{c}$ & 81.6 & $121.7 \mathrm{~d}$ & 79.1 \\
Trichoderma harazianum & $410.0 \mathrm{bc}$ & 51.9 & $691.7 \mathrm{a}$ & -18.8 \\
Pseudomonas flouroscence & $453.3 \mathrm{~b}$ & 46.8 & $350.0 \mathrm{bcd}$ & 39.9 \\
Trichoderma h. + Pseudomonasf.** & $558.3 \mathrm{~b}$ & 34.5 & $476.7 \mathrm{abc}$ & 18.2 \\
Untreated check & $851.7 \mathrm{a}$ & -- & $582.5 \mathrm{ab}$ & -- \\
\hline L.S.D. & 260.99 & -- & 243.64 & -- \\
\hline
\end{tabular}

Numbers followed by different letter(s) within a column are significantly different using LSD at $\mathrm{P}=0.05$.

*(D): Soil drench application at the rate of $11.11 \mathrm{ml} / \mathrm{l}$.

** The mixture was composed by the half dose of each $\left(2.5 * 10^{6}\right.$ spores $\left.+95 * 10^{4} \mathrm{CFU}\right) /$ plant.

These results were in agreement with those obtained by Sharma et al. (1997) and Pathan et al. (2005) who found that $P$. lilacinus along with Furadan ${ }^{\circledR}$ significantly reduced the number of galls / plant, egg-masses / root and eggs/ egg-mass, the number of larvae / $200 \mathrm{~g}$ soil and females/ $5 \mathrm{~g}$ root. Also, Sharma et al. (2008) found that Pseudomonas fluorescens decreased nematode penetration and galling by 54 and $70 \%$, respectively, compered with the untreated check.

In the case of egg masses, abamectin was the most effective treatment that gave $79.1 \%$ reduction, followed by oxamyl, $P$. flouroscence, cadusafos, carbofuran, fosthiazate, $T$. harazianum plus $P$. flouroscence achieving reduction percentages of $61.4,39.4,39.4$, $31.9,22.8$ and 18.2, respectively. Vice versa, $T$. harazianum was the least effective treatment in egg masses which gave an increase as low as $18.8 \%$.

3) Indirect effects of certain agrochemical and biological agents on the length and weight of the root system.

Data in Table(3) showed that Trichoderma harazianum was the most effective treatment to increase the root system length in the clay soil giving an increase of $39.1 \%$ over untreated check followed by cadusafos, fosthiazate, carbofuran, oxamyl, $P$. flouroscence and $T$. harazianum plus $P$. fluorescens which achieved 19.6, $17.2,17.2,15,6.8$ and $3.5 \%$ increase, respectively. It could be observed that there were no any significant differences between untreated check and all the running treatments except $T$. harazianum. Abamectin didn't showed any side effect on the root system length.

On the other hand, the highest increase of the root system fresh weight was induced by $T$. harazianum and fosthiazate, followed by carbofuran, $T$. harazianum plus
$P$. flouroscence, $P$. flouroscence, oxamyl, cadusafos and abamectin which gave 86.8, 85.5, 73.9, 62.8, 58.7, 54.8, 19.3 and $5.3 \%$ increase, respectively.

These findings are in agreement with those recorded by Alam et al.(1995) and Asawalam and Adesiyan (2001) who indicated that carbofuran improved the plant growth and increased mean fruit number and fruit weight. Also, Hafez and Sundararaj (2006) found that fosthiazate increased the total yield and the marketable yield of potato.

Tripathi and Singh (2006) found that the length and weight of root and shoot system significantly increased when tomato plants treated with Paecilomyces lilacinus and Trichoderma viride in combinations with mustard cake and Furadan.

4) Indirect effects of certain agrochemical and biological agents on the length and weight of the shoot system.

Data in Table (4) explain that the highest increase of the shoot system length was attaine by treatment of Trichoderma harazianum that gave $54.9 \%$ increase, followed by oxamyl, fosthiazate, $P$. flouroscence, cadusafos, carbofuran, abamectin and T. harazianum plus $P$. fluorescens that gave 46.8, 43.4, 42.7, 42.2, 40.4, 36.7 and $35.1 \%$ increase, respectively.

Moreover, Trichoderma harazianum recorded the highest increase of $87.8 \%$ in the shoot system fresh weight followed by oxamyl, fosthiazate, $P$. flouroscence, $T$. harazianum plus $P$. fluorescens, carbofuran, abamectin and cadusafos that gave descending percent increase amounted to 81.9, 78.1, $75.9,72.2,70.6,69.5$ and 67.9 , respectively.

Stephan (1995) and Rather et al. (2007) indicated that carbofuran treatments showed maximum plant 
growth, also Kavitha et al. (2007) found that Pseudomonas fluorescens, Bacillus subtilis and Trichoderma viride gave a significant increase in the plant growth parameters.

Trichoderma harzianum showed antagonistic effects against the root-knot (Meloidogyne incognita), and the possible mode of actions of this fungus were:

- The ability to colonize plant roots and penetrate into the epidermis by mechanisms similar to those of mycorrhizal fungi and to produce compounds that stimulate growth and plant defense mechanisms (Harman et al., 2004).
- Trichoderma strain may produce or release compounds that induce localized or systemic plant resistance responses (Harman et al., 2004).

- Trichoderma strains produce volatile and non volatile toxic metabolites such as, arzianic acid, alamethicins, tricholin, peptaibols antibiotics, 6penthyl- $\alpha$-pyrone, massoilactone, viridin, gliovirin, glisoprenins, heptelidic acid and others (Vey et al., 2001).

- The chitinolytic system of Trichoderma comprises many enzymes such proteases that together with chitinases are able to degrade nematode egg-shell thus helping penetration (Tikhonov et al., 2002).

Table 3. The influence of tested agrochemical and biological agents on length and weight of the root system of tomato plants

\begin{tabular}{lcccc}
\hline \multirow{2}{*}{ Treatments } & \multicolumn{4}{c}{ Root system } \\
\cline { 2 - 5 } & \multicolumn{2}{c}{ Length $(\mathbf{c m})$} & \multicolumn{2}{c}{ Fresh weight $(\mathbf{g})$} \\
\cline { 2 - 5 } & Average & $\begin{array}{c}\text { Increase } \\
(\boldsymbol{\%})\end{array}$ & Average & $\begin{array}{c}\text { Increase } \\
(\boldsymbol{\%})\end{array}$ \\
\hline Fosthiazate & $23.3 \mathrm{~b}$ & 17.2 & $49 \mathrm{a}$ & 85.5 \\
Carbofuran & $23.3 \mathrm{~b}$ & 17.2 & $27.2 \mathrm{~b}$ & 73.9 \\
Cadusafos & $24.0 \mathrm{~b}$ & 19.6 & $8.8 \mathrm{~b}$ & 19.3 \\
Oxamyl & $22.7 \mathrm{~b}$ & 15.0 & $15.7 \mathrm{~b}$ & 54.8 \\
Abamectin D* & $19.3 \mathrm{~b}$ & 0.0 & $7.5 \mathrm{~b}$ & 5.3 \\
Trichoderma harazianum & $31.7 \mathrm{a}$ & 39.1 & $53.9 \mathrm{a}$ & 86.8 \\
Pseudomonas flouroscence & $20.7 \mathrm{~b}$ & 6.8 & $16.8 \mathrm{~b}$ & 58.7 \\
Trichoderma h.+ Pseudomonas $f . * *$ & $20.0 \mathrm{~b}$ & 3.5 & $19.1 \mathrm{~b}$ & 62.8 \\
Untreated check & $19.3 \mathrm{~b}$ & -- & $7.1 \mathrm{~b}$ & -- \\
L.S.D. & 5.73 & -- & 19.93 & -- \\
\hline
\end{tabular}

Numbers followed by different letter(s) within a column are significantly different using LSD at $\mathrm{P}=0.05$.

*(D): Soil drench application at the rate of $11.11 \mathrm{ml} / \mathrm{l}$.

** The mixture was composed by the half dose of each $\left(2.5^{*} 10^{6}\right.$ spores $\left.+95^{*} 10^{4} \mathrm{CFU}\right) /$ plant.

Table 4. The influence of tested agrochemical and biological agents on length and weight of the shoot system of tomato plants

\begin{tabular}{|c|c|c|c|c|}
\hline \multirow[b]{3}{*}{ Treatments } & \multicolumn{4}{|c|}{ Shoot system } \\
\hline & \multicolumn{2}{|c|}{ Length $(\mathrm{cm})$} & \multicolumn{2}{|c|}{ Fresh weight $(\mathrm{g})$} \\
\hline & Average & $\begin{array}{c}\text { Increase } \\
(\%)\end{array}$ & Average & $\begin{array}{c}\text { Increase } \\
(\%)\end{array}$ \\
\hline Fosthiazate & $78.3 \mathrm{~b}$ & 43.4 & $190.0 \mathrm{bc}$ & 78.1 \\
\hline Carbofuran & $74.3 \mathrm{~b}$ & 40.4 & $141.7 \mathrm{bc}$ & 70.6 \\
\hline Cadusafos & $76.7 \mathrm{~b}$ & 42.2 & $130.0 \mathrm{c}$ & 67.9 \\
\hline Oxamyl & $83.3 \mathrm{ab}$ & 46.8 & $230.0 \mathrm{~b}$ & 81.9 \\
\hline Abamectin D* & $70.0 \mathrm{~b}$ & 36.7 & $136.7 \mathrm{bc}$ & 69.5 \\
\hline Trichoderma harazianum & $98.3 \mathrm{a}$ & 54.9 & $341.7 \mathrm{a}$ & 87.8 \\
\hline Pseudomonas flouroscence & $77.3 \mathrm{~b}$ & 42.7 & $173.3 \mathrm{bc}$ & 75.9 \\
\hline Trichoderma h. + Pseudomonas $f . * *$ & $68.3 \mathrm{~b}$ & 35.1 & $150.0 \mathrm{bc}$ & 72.2 \\
\hline Untreated check & $44.3 \mathrm{c}$ & ----- & $41.7 \mathrm{~d}$ & ----- \\
\hline L.S.D. $\mathbf{0 . 0 5}_{1}$ & 17.57 & ----- & 86.09 & ----- \\
\hline
\end{tabular}

Numbers followed by different letter(s) within a column are significantly different using LSD at $\mathrm{P}=0.05$.

*(D): Soil drench application at the rate of $11.11 \mathrm{ml} / \mathrm{l}$.

** The mixture was composed by the half dose of each $\left(2.5^{*} 10^{6}\right.$ spores $\left.+95^{*} 10^{4} \mathrm{CFU}\right) /$ plant. 


\section{REFERENCES}

Alam, K.S.; M.U. Ahmed; I. Hossain and A.K.M.A. Haque (1995). Efficacy of dholkalmi (Ipomoea fistulosa) and Furadan to control root-knot nematode, Meloidogynejavanica on brinjal. Bangladesh J. Plant Pathol., 11(1-2): 33-35.

Asawalam, E.F. and S.O. Adesiyan (2001). Comparison of nematicidal potentials of Azadirachta indica and carbofuran $\left(\right.$ Furadan $\left.^{\circledR}\right)$ on the growth and yield of rootknot nematode infested okra. J. Sust. Agric. Enviro., 3(1): 85-92.

Badawi, S.M. and W.I. Abu-Gharbieh (2000). Efficacy of certain non-fumigant nematicides for the control of Meloidogyne javanica on tomato. Pakistan J. Nematol., 18(1/2): 59-68.

Barker, K. R. (1985). Sampling nematode communities. pp317. In Barker, K. R.; C. C. Carter and J. N. Sasser, eds. An advanced treatise on Meloidogyne, vol. 11, Methodology. North Carolina State Univ. Graphics.

Castagnone-Sereno, P. (2002). Genetic variability in parthenogenetic root-knot nematodes, Meloidogyne spp. and their ability to overcome plant resistance genes. Nematologica, 4: 605-608.

Corbett, J. R.; K. Wright and A. C. Baillie (1984). The biochemical mode of action of pesticides. Second Edition. London, Academic Press, 382 p.

Duncan, D.B. (1955). Multiple range and multiple $\mathrm{F}$ tests. Biometrics, 11: 1-41.

Faske, T.R. and J.L. Starr (2007). Cotton root protection from plant-parasitic nematodes by abamectin treated seed. J. Nematol., 39 (1): 27-30.

Gamlie, A.and J. Katan (1993). Suppression of major and minor pathogens by fluorescent pseudomonads in solarized and non solarized soil. Phytopathology, 83: 6875.

Hafez, S. L. and P. Sundararaj (2006). Efficacy of fosthiazate for the control of Paratrichodorus spp. and Meloidogyne chitwoodi on potato. Int. J. Nematol., 16(2): 157-160.

Harman, G.E.; C.R. Howell; A.Viterbo; I. Chet and M. Lorito (2004). Trichoderma species opportunistic, avirulent plant symbionts. Nature Reviews, 2:43-56.

Henderson, C.F. and E.W. Tilton (1955). Tests with acaricides against the brown wheat mite. J. Econ. Entomol., 48:157160.

Holbrook, C.C.; D. A. Knauft and D.W. Dikson (1983). A technique for screening peanut for resistance to Meloidogyne arenaria. Plant Dis., 57: 957-958.

Howeedy, A.; N. G. henna; A. Shawkey and F. Abdel-Aziz (2003). Tomato production and cultivate. Technique Bulletin No. 816 of Agricultural Research Center. pp. 84.
Ibrahim, I. K. A. (1985). The status of root-knot nematodes in the middle east region VII of the International Meloidogyne project. In: Advanced Treatise on Meloidogyne vol.1 Biology and Control. J.N.Sasser and C.C.Carter (Eds.). North Carolina State Univ.Raleigh, N,C, USA.

Imran,A. S.; S. S. Shaukat' I. H. Sheikh and A. Khan (2006). Role of cyanide production by Pseudomonas fluorescens CHA0 in the suppression of root-knot nematode, Meloidogyne javanica in tomato. World J. Microbio.Biotechnol., 22: 641-650.

Kavitha, J.; E.I. Jonathan and R. Umamaheswari (2007). Field application of Pseudomonas fluorescens, Bacillus subtilis and Trichoderma viride for the control of Meloidogyne incognita (Kofoid and White) Chitwood on sugarbeet. J. Bio. Control, Society for Biocontrol Advancement, Bangalore, India, 21 (2): 211-215.

Krishnaveni, M. and S. Subramanian (2004). Evaluation of biocontrol agents for the management of Meloidogyne incognita on cucumber (Cucumis sativus L). Current Nematology, 15(1/2): 33-37.

Monfort, W. S.; T. L.Kirkpatrick; D. L. Long and T. Rideot (2006). Efficacy of a novel nematicidal seed treatment against Meloidogyne incognita on cotton. J. Nematol., 38 (2): 245-249.

Noling, J. W. and J. O. Becker (1994). The challenge of research and extension to define and implement alternatives to methyl bromide. J. Nematol., 26 (Suppl.): 573-586.

Oostendrop, M. and R.A. Sikora (1989). Utilization of antagonistic rhizobacteria as a seed treatment for the biological control of Heterodera schachtii in sugarbeet. Revue de Nematology, 12: 77-83

Pathan, M.A.; S.H. Soomro; M.M. Jiskani; K.H. Wagan and J.A. Memon (2005). Effect of Paecilomyces lilacinus and furadan on plant growth, root nodulation and reproduction of Meloidogyne incognita in tomato. Pakistan J. Nematol., 23(1): 67-71.

Rather, M.A.; F. Ahmad and M.A. Siddiqui (2007). Combined influence of neem part products and or two nematicides against root-knot nematode, Meloidogyne incognita on field grown tomato. Pakistan J. Nematol., 25(2): 305-311.

Siddiqui, Z.A. and I. Mahmood (1998). Effect of a plant growth promoting bacterium, an AM fungus and soil types on the morphometrics and reproduction of Meloidogyne javanica on tomato. Appl. Soil Ecol., 8: 77-84.

Sharma, D.D. (1999). Effect of culture filtrates of biocontrol agents on larval mortality of Meloidogyne incognita, in comparison with Rugby 10G. Indian J. Sericulture. 38(2): 152-154.

Sharma, R.; S.S. Dhaliwal and P.S. Chandurkar (1997). Evaluation of chemical and botanical nematicides for nematode management on brinjal. Indian J. Plant Protection, 25(1): 4-7. 
Sharma, H.K.; A. Kamra; Pankaj; J. Lal and J. Kumar (2008). Effect of seed treatment with Pseudomonas fluorescens alone and in combination with soil application of carbofuran and neem seed powder against Meloidogyne incognita in okra. Pesticide Research, J. Soc. Pesticide Sci. India, New Delhi, India, 20 (1): 79-82.

Stephan, Z.A. (1995). The efficacy of nematicides and horse manure in controlling root-knot nematodes on tomato and eggplant. Nematologia Mediterranea, 23(1): 29-30.
Tikhonov, V.E.; L.V. Lopez-Llorca; J. Salinas and H.B.Jansson (2002). Purification and characterization of chitinases from the nematophagous fungi Verticillium chlamydosporium and V. suchlasporium. Fung. Gen. Biol., 35: 67-78.

Tripathi, P.K. and C.S. Singh (2006). Effect of some compatible biocontrol agents along with mustard cake and Furadon on Meloidogyne incognita infecting tomato plant. Indian J. Nematol.,36(2): 309-311.

Vey, A.; R.E. Hoagland and T.M. Butt (2001). Toxic metabolites of fungal biocontrol agents. In: Butt, T.M.; C. Jackson and N. Magan (eds) Fungi as biocontrol agents:

Progress, problems and potential. CAB International Bristol, pp 311-346. 


\section{الملخص العربي}

\section{تقييم بعض المبيدات النيماتودية والكائنات المضادة على نيماتودا تعقد الجذذورالمتطفلة على نباتات الطماطم}

$$
\text { هالة سعد إبراهيم، عبد الفتاح سيدعبدالكريم سعد، مجدى عبد الظاهر مسعود، تُمَّمَ صلاح الدين حسن خليل }
$$

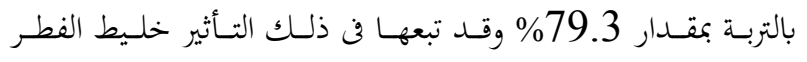

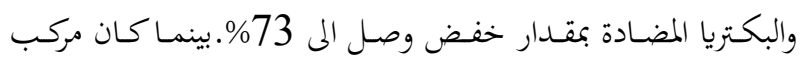
الأبامكتين أفضل المعاملات المختبرة في خفض العقد النيا والنيماتودية وكتل البيض/ 5جم جذوربمقدار6.81. و و 79.1\% على التوالى.

ولقد أوضحت النتائج أيضا فاعلية الفطر المضاد Trichoderma

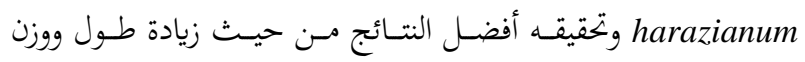

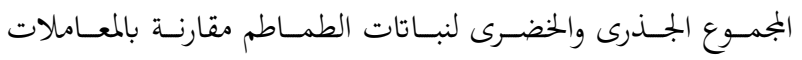
الأخرى.
تم تقييم بعض المبيـدات النيماتوديـة ( الفوزثيازيت, الأوكسـاميل,

الكـاربوفيوران, الكادوسـافوس) وأحسـ المركبـات الحيويـة (الأبامكتـين)

وكـلك أحسد الفطريات المضـادة (Trichoderma harazianum) وبكتريا مضادة (Pseudomonas flouroscence) لدراسة تأثيرهـا على نيماتودا تعقد الجذور Meloidogyne incognita التى تصيب نباتات الطماطم في التربة الطينية تحت ظروف الصوب البلاستيكية.

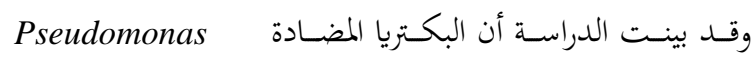
flouroscence منفردة أعطت أفضل النتائج في خفض تعداد اليرقات 